SCHALLER, H. W.: Ukrainistik in Europa. Peter Lang, 2013.

Slavica litteraria. 2011, č. 1. Hungaroslavica. Památce prof. PhDr. Richarda Pražáka, DrSc. (1931-2010).

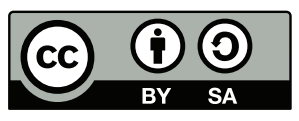

Toto dílo Ize užít v souladu s licenčními podmínkami Creative Commons BY-SA 4.0 International (<https:// creativecommons.org/licenses/by-sa/4.0/legalcode>). Uvedené se nevztahuje na díla či prvky (např. obrazovou či fotografickou dokumentaci), které jsou v díle užity na základě smluvní licence nebo výjimky či omezení príslušných práv.

https://doi.org/10.5817/OS2020-1-13

\title{
N. V. Gogol v proudu literárního vývoje
}

КРИВОНОС, В.Ш.: Гоголь в русском литературном пространстве XIX-XX вв. Самара: Министерство образования и науки Российской Федерации, Федеральное государственное образовательное учреждение высшего образования «Самарский государственный социально-педагогический университет», 2017. 268 c. ISBN 978-5-8428-1095-6.

Monografie jednoho z největších současných ruských znalců Gogolovy tvorby, samarského profesora Vladislava Šajeviče Krivonosa, by se asi dala snadno nazvat vzorovou přehlídkou toho, jak Gogol tvořivě čerpal z inspiračních zdrojů druhých autorů a jak jiní autoři čerpali inspiraci z jeho děl, a to nejen po formální stránce.

Ve 14 minuciózně zpracovaných studiích se autor zabývá zcela konkrétními místy jím zvolených literárních děl a prokazuje jak mimořádnou znalost Gogolových textů, tak stejně dobrou znalost textů děl těch autorů, jež do souvislosti s Gogolovou tvorbou dává. Díky tomu pak poukazuje na tematické či typologické souvislosti, at již záměrné nebo někdy zřejmě spíše intuitivní. Každá z kapitol - či spíše ze studií - je věnována konkrétnímu srovnání Gogolových textů s texty řady jeho předchůdců, současníků i následníků, přičemž samozřejmě nepretenduje na úplnost a na postižení všech možných pohledů.

Podstatné je, že díky srovnání zvolených textů dokáže V. S. Krivonos najít doložitelné společné znaky zkoumaných děl. Tak např. pro postavy Čackého v Gribojedovově Hoři z rozumu a Čičikova z Gogolových Mrtvých duši tyto sjednocující rysy nachází v obracení se ke kategorii rozumu, byte, jak autor monografie konstatuje, se její základní existenciální a ontologické traktování vztahuje u Gribojedova k filozofické tradici, u Gogola pak k tradici mravoučné a religiózní (s. 29). Tradovaný inspirativní vliv 
Puškinových děl na Gogolovu tvorbu dokládají dvě studie - jedna sledující projevy kategorií воля а доля v Puškinově poémě Cikáni a Gogolově Tarasu Bulbovi a druhá uvádějící typologicky posunuté podobnosti hrdinů z Pikové dámy v Mrtvých duších.

Monografie si však všímá i méně „frekventovaných“ autorů, takže v ní najdeme mimo jiné studie věnované souvislostem mezi Gogolovými díly a texty O. Senkovského, P. de Kocka, D. Merežkovského, L. Loseva či L. Giršoviče. Tyto i další dílčí studie utvrzují čtenáře v tom, nakolik pevně je Gogol svou tvorbou vkotven do dobového literárního kontextu první poloviny 19. století, ukazují rovněž „fenomén Gogol“ jako na jev, který prochází ruskou literaturou i nadále, a to až do postmodernistické intertextově pojaté fikce.

V.Š. Krivonos vychází ve svých primárně komparativně pojatých analýzách především za naratologických východisek, ani zdaleka se však u nich nezastavuje a všímá si i typologických prvků „výstavby“ postav, konstrukce i funkce časových a prostorových dimenzí, neuniká mu modus výpovědi o zobrazovaném světě. Projevuje při tom mimořádnou akribii, opíraje se o velké množství sekundárních zdrojů, které někdy poopravuje či je posouvá ještě bližze konkrétním pojednávaným textům a jejich specifickým vlastnostem.

Volba autorů, již jsou v jednotlivých studiích dáváni do souvislosti s Gogolovou tvorbou, pak možná více než na samotného Gogola poukazuje na kontinuitu ruské literatury, na to, že určité tematické „uzly“ přitahují pozornost autorů v různých dobách, že jsou tyto jevy funkčně zapojovány do nově vznikajících děl a vytvářejí tak vývojové kontinuum, které je sice spjato s Gogolem (at již jako následovníkem či jako iniciátorem), ale typologicky i sémanticky na něm není ani závislé, ani nepěstuje jeho nedotknutelnost, ba leckdy jej transponuje či paroduje.

fosef Dohnal

\section{Literatura:}

KRIVONOS, V.Š.: Gogol' v russkom literaturnom prostranstve XIX-XX vv. Samara: Ministerstvo obrazovanija i nauki Rossijskoj Federacii, Federal'noje gosudarstvennoje obrazovatel'noje učreždenije vysšego obrazovanija «Samarskij gosudarstvennyj social'no-pedagogičeskij universitet», 2017. 268 s. ISBN 978-5-8428-1095-6.

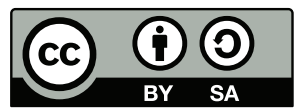

Toto dílo Ize užít v souladu s licenčními podmínkami Creative Commons BY-SA 4.0 International (<https:// creativecommons.org/licenses/by-sa/4.0/legalcode>). Uvedené se nevztahuje na díla či prvky (např. obrazovou či fotografickou dokumentaci), které jsou v díle užity na základě smluvní licence nebo výjimky či omezení př́slušných práv. 